\title{
Use of multivitamin, acidifier and Azolla in the diet of broiler chickens
}

\author{
M. A. Islam ${ }^{1,2, *}$ and M. Nishibori ${ }^{2}$
}

* Corresponding Author: M. A. Islam Tel: +88-02-9205310(14/2150), Fax: +88-02-

9205333,E-mail: aminul_dgvc@yahoo.com

'Department of Dairy and Poultry Science, Bangabandhu Sheikh Mujibur Rahman Agricultural University, Gazipur-1706, Bangladesh

${ }^{2}$ Graduate School of Biosphere Science, Hiroshima

University, Higashi-Hiroshima, 739-8528, Japan

Submitted May 19, 2016; Revised Jul 11, 2016: Accepted Aug 8, 2016
Objective: The experiments were carried out to measure the effect of multivitamin, acidifier and Azolla on growth performance, profitability and lipid profiles of blood of broiler chickens to produce safe and cost effective broilers.

Methods: In experiment 1, 240 day-old Cobb-500 broiler chicks were fed diets; $\mathrm{D}_{1}$ (control), $\mathrm{D}_{2}\left(\mathrm{D}_{1}\right.$ with $1 \mathrm{~mL}$ multivitamin/liter water), $\mathrm{D}_{3}\left(\mathrm{D}_{1}\right.$ with $1 \mathrm{~mL}$ acidifier/liter water $), \mathrm{D}_{4}\left(\mathrm{D}_{1}\right.$ with $1 \mathrm{~mL}$ multivitamin and $2 \mathrm{~mL}$ acidifier/liter water) having 3 replications in each, and 20 chicks/replication. In experiment 2, 150 day-old Cobb-500 broiler chicks were fed diets; $\mathrm{T}_{1}$ (control), $\mathrm{T}_{2}$ (5\% Azolla in the diet), $\mathrm{T}_{3}$ (7\% Azolla in the diet) and $\mathrm{T}_{4}$ ( $\mathrm{T}_{1}$ with $1 \mathrm{~mL}$ multivitamin and $1 \mathrm{~mL}$ acidifier/liter water) having 3 replications in each, and 20 chicks/replication in control, and 10 chicks/replication in the remaining dietary treatment groups for 35 days. Results: In experiment 1 , the highest live weight was observed in $\mathrm{D}_{4}(\mathrm{p}<0.05)$, however, feed intake was statistically similar between diets $(\mathrm{p}>0.05)$. The lowest feed conversion ratio (FCR) $(\mathrm{p}<0.001)$ and mortality $(\mathrm{p}<0.05)$ were observed in $\mathrm{D}_{2}$ followed by $\mathrm{D}_{4}, \mathrm{D}_{1}$, and $\mathrm{D}_{3}$, respectively. There were no significant differences between diets for feed cost and net profit $(p>0.05)$. However, evidently but not significantly, the highest net profit was obtained in $\mathrm{D}_{2}$ followed by $\mathrm{D}_{4}, \mathrm{D}_{1}$, and $\mathrm{D}_{3}$, respectively. In experiment 2 , the highest live weight $(\mathrm{p}<0.05)$ and feed intake $(\mathrm{p}<0.001)$ were observed in $\mathrm{T}_{4}$. Mortality $(\mathrm{p}<0.01)$, FCR $(\mathrm{p}<0.01)$, feed cost $(\mathrm{p}<0.05)$ and net profit $(\mathrm{p}<0.05)$ were significantly different among diets. Considering net profit, $\mathrm{T}_{2}$ was the best performing dietary group followed by $\mathrm{T}_{3}, \mathrm{~T}_{1}$, and $\mathrm{T}_{4}$, respectively. The lowest lipid profiles were observed in $\mathrm{D}_{3}$ followed by $\mathrm{D}_{1}, \mathrm{D}_{4}$, and $\mathrm{D}_{2}$, respectively $(\mathrm{p}<0.05)$. In experiment 2 , the lowest total cholesterol, TG, and the highest amount of high density lipoprotein were observed in $\mathrm{T}_{2}$, followed by $\mathrm{T}_{3}, \mathrm{~T}_{1}$, and $\mathrm{T}_{4}$, respectively $(\mathrm{p}<0.05)$. Evidently but not significantly, low density lipoprotein was the highest in $\mathrm{T}_{2}$ followed by $\mathrm{T}_{3}, \mathrm{~T}_{4}$, and $\mathrm{T}_{1}$, respectively $(\mathrm{p}>0.05)$. Conclusion: In conclusion, Azolla and acidifier reduced lipid profiles of broiler chickens. Considering net profit and lipid profiles, $5 \%$ Azolla may be the suitable dietary group for producing safe and profitable broilers. However, more studies are needed to confirm this study prior to suggesting using Azolla in the poultry industry.

Keywords: Acidifier; Azolla; Broiler Growth; Lipid Profiles; Multivitamin

\section{INTRODUCTION}

Chickens are susceptible to vitamin deficiency because their gut flora can synthesize only a small amount of vitamins, and in intensive systems of rearing chickens undergoe many stresses [1]. Poultry diets usually contain meager amounts of vitamin $\mathrm{A}$, riboflavin and $\mathrm{B}_{12}$. In addition, farmers are randomly using unexpected growth promoters, antibiotics, hormones, enzymes, and protein concentrates containing heavy metals to produce rapid growth of chickens although these additives may have a harmful effect on poultry as well as on humans. For these reasons, poultry scientists are trying to establish alternative poultry production using improved genotypes (e.g. naked neck), feeding, and access to an outdoor area to produce safe and profitable poultry 
production [2]. Vitamin metabolites; $\mathrm{D}_{3}, 25(\mathrm{OH}) \mathrm{D}_{3}$ and $1,25(\mathrm{OH}) \mathrm{D}_{3}$ influence growth performance, feed:gain and bone quality however, vitamin $1 \alpha(\mathrm{OH}) \mathrm{D}_{3}$ has a negative effect reducing weight gain and feed:gain [3]. Azolla, multivitamin or acidifier were used in the present study with the goal of producing safe and profitable broilers. Supplementation of multivitamins in formulated diets is indispensable because blending feed ingredients may not ensure that all the essential vitamins such as Vitamin A, D, E, folic acid, pantothenic acid, pyridoxine, riboflavin, and so on are present in the correct amount required for chickens. Supplementation of multivitamins in broiler diets increases body weight as well as meat yield, and protects against deficiency diseases, and reduces mortality $[4,5]$.

Organic acids (lactic, acetic, propionic, and butyric) with feed or drinking water improves its quality, and maintains the $\mathrm{pH}$ of digesta at a level preventing the growth of pathogenic bacteria. Acidifiers supplementation in broiler diets improve growth performance through establishment of a low gastro-intestinal $\mathrm{pH}$ condition by supporting endogenous digestive enzymes, and reducing undesired gut microorganisms [6-8].

Azolla is the cheapest and abundant unconventional plant protein source that improves feed conversion efficiency, energy efficiency, and economic performance without any deleterious effects on birds or humans [9-11]. Studies demonstrated that Azolla (5\%) improves feed conversion efficiency, dressing yield, profitability, and reduce mortality and blood cholesterol of broilers [12-14]. Another study concluded that Azolla (7.5\%) affects body weight and immunity of broiler chickens because of it can assimilate atmospheric N2, due to the presence of algal symbionts in its leaves [15]. Feeding studies revealed that fresh Azolla can replace about 20\% commercial feed of chickens [16].

However, there has been no comparative study regarding the effect of Azolla and multivitamin or acidifier on growth performance, profitability and lipid profiles of broiler chickens. In addition, no work has been done to determine whether Azolla may be a profitable and suitable feed additive to include in broiler diets. Therefore, the present study was planned to assess the comparative effect of multivitamins, acidifiers and Azolla, either alone or combination, on growth performance, profitability and lipid profiles of broiler chickens for producing safe and cost effective broiler.

\section{MATERIALS AND METHODS}

\section{Experimental design and dietary treatment groups}

Experiment 1: A total of 240 Cobb-500 day-old straight run broiler chicks were distributed in to four dietary treatment groups (control group and 3 treatment groups) having 3 replications in each, and 20 chicks/replication for a period of 35 days.

Experiment 2: A total of 150 Cobb-500 day-old straight run broiler chicks were distributed in to four dietary treatment groups (control group and 3 treatment groups) having 3 replications in each, and 20 chicks/replication in control, and 10 chicks/replication in dietary treatment groups for a period of 35 days.

\section{Collection and preparation of Azolla meal}

Azolla pinnata were cultivated in a fresh water pond of the Faculty of Fisheries, Bangabandhu Sheikh Mujibur Rahman Agricultural University (BSMRAU) Gaziur, Bangladesh. During Azolla cultivation, TSP and MP fertilizer were used in the pond. Fresh Azolla was collected in every week, and dried in the sun in order to grind using a grinder. Thereafter, it was used in the experimental diet of the broilers.

\section{Feeding and management}

The iso- nitrogenous and iso- caloric starter diet (0 to 3 weeks) containing 22\% crude protein (CP) and 2,900 kcal metabolizable energy (ME) $/ \mathrm{kg}$, and finisher diet (4 to 5 weeks) containing $21 \%$ $\mathrm{CP}$ and 3,000 kcal ME/kg were provided to the birds. The birds were fed diets; $\mathrm{D}_{1}$ (control diet, no multivitamin or acidifier), $\mathrm{D}_{2}\left(\mathrm{D}_{1}\right.$ with supplementation of $1 \mathrm{~mL}$ multivitamin/liter drinking water), $D_{3}\left(D_{1}\right.$ with supplementation of $1 \mathrm{~mL}$ acidifier/liter drinking water) and $\mathrm{D}_{4}\left(\mathrm{D}_{1}\right.$ with supplementation of $1 \mathrm{~mL}$ multivitamin and $2 \mathrm{~mL}$ acidifier/liter drinking water) in experiment 1, and $\mathrm{T}_{1}$ (control diet-no Azolla or multivitamin and acidifier), $\mathrm{T}_{2}$ (5\% Azolla in the diet), $\mathrm{T}_{3}$ (7\% Azolla in the diet) and $\mathrm{T}_{4}\left(\mathrm{~T}_{1}\right.$ with supplementation of $1 \mathrm{~mL}$ multivitamin and $1 \mathrm{~mL}$ acidifier/liter drinking water) in experiment 2 for a period of 35 days (Table 1). The birds were reared on floor management system with a stocking density of one (1) sq. ft/bird. The birds were offered diet and clean-fresh water ad libitum, and exposed to $23.5 \mathrm{hrs}$ lighting regime up to the marketable age (35 days).

\section{Data recording}

Body weight and feed intake were recorded fortnightly, and number of dead bird was recorded when occurred. The feed conversion ratio (FCR) was calculated from feed intake and live weight of broiler at the end of experiment. The production cost (Bangladeshi currency Taka/kg live broiler) was calculated considering cost of day-old chicks, feed, labor, litter, vaccine, medicine, and so on. The net profit was calculated from the sale, and production cost $/ \mathrm{kg}$ live broiler. To measure lipid profiles (Total cholesterol, high density lipoprotein [HDL], triglyceride [TG], and low density lipoprotein [LDL]), $5 \mathrm{~mL}$ blood from one broiler chicken/replication was collected at the end of experiment, and then the serum separated using a centrifuge. Individual serum was used to estimate lipid profiles following spectrophotometric methods. The CRESCENT DIAGNOSTICS cholesterol test kits (Cat No. CS 603, Jeddah 21423, Saudi-Arabia) were used to determine lipid profiles of blood of broiler chickens.

The recorded ambient temperature, humidity and rainfall during the experimental period of experiment 1 , and experiment 
Table 1. Composition of diet used in the experiment

\begin{tabular}{|c|c|c|c|c|c|c|c|c|}
\hline \multirow{3}{*}{ Items } & \multicolumn{2}{|c|}{ Experiment $1^{1)}$} & \multicolumn{6}{|c|}{ Experiment $2^{2)}$} \\
\hline & \multirow{2}{*}{$\begin{array}{c}\text { Starter diet }(\mathrm{kg}) \\
\mathrm{D}_{1}\end{array}$} & \multirow{2}{*}{$\frac{\text { Finisher diet }(\mathrm{kg})}{\mathrm{D}_{1}}$} & \multicolumn{3}{|c|}{ Starter diet (kg, 0 to 3 weeks) } & \multicolumn{3}{|c|}{ Finisher diet (kg, 4 to 5 weeks) } \\
\hline & & & $\mathrm{T}_{1}$ & $\mathrm{~T}_{2}$ & $\mathrm{~T}_{3}$ & $\mathrm{~T}_{1}$ & $\mathrm{~T}_{2}$ & $\mathrm{~T}_{3}$ \\
\hline \multicolumn{9}{|l|}{ Ingredients } \\
\hline Maize & 64.50 & 65.00 & 64.50 & 61.50 & 61.00 & 65.00 & 63.50 & 62.50 \\
\hline Soybean meal & 27.00 & 26.50 & 27.00 & 24.50 & 23.00 & 26.50 & 23.00 & 22.00 \\
\hline Protein concentrate & 7.00 & 6.00 & 7.00 & 7.00 & 7.00 & 6.00 & 6.00 & 6.00 \\
\hline Azolla $a^{3)}$ & - & - & - & 5.00 & 7.00 & - & 5.00 & 7.00 \\
\hline Soybean oil & - & 1.00 & - & 0.50 & 0.50 & 1.00 & 1.00 & 1.00 \\
\hline DCP & 1.00 & 1.00 & 1.00 & 1.00 & 1.00 & 1.00 & 1.00 & 1.00 \\
\hline Salt & 0.50 & 0.50 & 0.50 & 0.50 & 0.50 & 0.50 & 0.50 & 0.50 \\
\hline Total & 100.00 & 100.00 & 100.00 & 100.00 & 100.00 & 100.00 & 100.00 & 100.00 \\
\hline \multicolumn{9}{|l|}{ Calculated composition } \\
\hline Crude protein (CP)\% & 22.25 & 21.49 & 22.25 & 22.19 & 21.98 & 21.49 & 21.08 & 21.05 \\
\hline ME (kcal/kg) & $2,943.28$ & $3,009.66$ & $2,943.28$ & $2,934.03$ & $2,924.55$ & $3,009.66$ & $2,983.00$ & $2,968.41$ \\
\hline $\mathrm{Ca}(\%)$ & 0.73 & 0.67 & 0.73 & 0.78 & 0.80 & 0.67 & 0.72 & 0.74 \\
\hline Av. P (\%) & 0.71 & 0.68 & 0.71 & 0.76 & 0.77 & 0.68 & 0.72 & 0.74 \\
\hline Lysine (\%) & 1.21 & 1.16 & 1.21 & 1.18 & 1.15 & 1.16 & 1.10 & 1.09 \\
\hline Methionine (\%) & 0.43 & 0.41 & 0.43 & 0.43 & 0.42 & 0.41 & 0.40 & 0.50 \\
\hline Cystine (\%) & 0.39 & 0.38 & 0.39 & 0.38 & 0.37 & 0.38 & 0.36 & 0.35 \\
\hline
\end{tabular}

$\mathrm{CP}$, crude protein; $\mathrm{ME}$, metabolizable energy.

${ }^{1)} \mathrm{D}_{1}$, control diet (no multivitamin or acidifier); $\mathrm{D}_{2}, \mathrm{D}_{1}$ with $1 \mathrm{~mL}$ multivitamin/liter water; $\mathrm{D}_{3}, \mathrm{D}_{1}$ with $2 \mathrm{~mL}$ acidifier/liter water; $\mathrm{D}_{4}, \mathrm{D}_{1}$ with $1 \mathrm{~mL}$ multivitamin and $2 \mathrm{~mL}$ acidifier/liter water.

${ }^{2)} T_{1}$, control diet (no Azolla or multivitamin and acidifier); $T_{2}, 5 \%$ Azolla in the diet; $T_{3}, 7 \%$ Azolla in the det; $T_{4}, T_{1}$ with $1 \mathrm{~mL}$ multivitamin and $1 \mathrm{~mL}$ acidifier/liter water.

${ }^{3)}$ Composition of Azolla meal: CP, 25.78\%; ME (kcal/kg), 2,039; Ca, 2.58\%; Av. P, 0.29\%; Lysine, 0.98\%; Methionine, 0.34\%; Tryptophan, 0.39\%; Cystine, 0.18\%; CF, 14\% (Alalade and Lyayi [10]).

2 were $19.8^{\circ} \mathrm{C}, 80.5 \%$ and $8.4 \mathrm{~mm}$, and $28.2^{\circ} \mathrm{C}, 82.5 \%$ and 311.3 $\mathrm{mm}$, respectively.

\section{Statistical analysis}

The collected data were analyzed in completely randomized design using MSTAT-C [17] computer package program.

Statistical model: The following statistical model was used for data analysis.

$$
\mathrm{Y}_{\mathrm{ij}}=\mu+(\mathrm{D} \text { or } \mathrm{T})_{\mathrm{i}}+\mathrm{e}_{\mathrm{ij}}
$$

Where, $\mathrm{Y}_{\mathrm{ij}}$ is the observation on jth replication of ith dietary treatment group, $\mu$ is the overall mean, $(\mathrm{D} \text { or } \mathrm{T})_{\mathrm{i}}$ is the fixed effect of ith dietary treatment group $(i=1,2,3,4)$, and $e_{i j}$ is the random error.

\section{RESULTS}

\section{Experiment 1}

Growth performance of broiler fed diet with or without multivitamin or acidifier at 35 days of age: Live weight $(\mathrm{p}<0.05)$ and FCR $(\mathrm{p}<0.001)$ were significantly different among the diets; $\mathrm{D}_{1}$ (control diet, no multivitamin or acidifier), $\mathrm{D}_{2}\left(\mathrm{D}_{1}\right.$ with supplementation of $1 \mathrm{~mL}$ multivitamin/liter drinking water), $\mathrm{D}_{3}\left(\mathrm{D}_{1}\right.$ with supplementation of $1 \mathrm{~mL}$ acidifier/liter drinking water) and $\mathrm{D}_{4}\left(\mathrm{D}_{1}\right.$ with supplementation of $1 \mathrm{~mL}$ multivitamin and 2 $\mathrm{mL}$ acidifier/liter drinking water) (Table 2). In terms of live weight and FCR, test diets were superior to control diet $\left(D_{1}\right)$.

Table 2. Effect of multivitamin or acidifier on growth performance of broiler chickens at 35 days of age

\begin{tabular}{|c|c|c|c|c|c|c|}
\hline \multirow{2}{*}{ Parameters } & \multicolumn{4}{|c|}{ Diet (D) } & \multirow{2}{*}{$\frac{\text { SEM or } x^{2} \text { value }}{\text { D }}$} & \multirow{2}{*}{$p$-value } \\
\hline & $D_{1}$ & $\mathrm{D}_{2}$ & $D_{3}$ & $\mathrm{D}_{4}$ & & \\
\hline Live weight (g/bird) & $1,315.10$ & $1,471.67$ & $1,335.82$ & $1,606.13$ & 72.341 & 0.01 \\
\hline Feed intake (g/bird) & $2,233.43$ & $2,345.80$ & $2,228.79$ & $2,069.97$ & 93.746 & 0.10 \\
\hline FCR (feed/live weight) & 1.70 & 1.59 & 1.67 & 1.29 & 0.045 & $<0.01$ \\
\hline Mortality (\%) & 6.67 & 0 & 16.67 & 8.33 & $x^{2}=13.994$ & 0.01 \\
\hline Production cost (TK/kg live broiler) & 97.04 & 89.97 & 106.74 & 91.99 & 7.416 & 0.19 \\
\hline Net profit (TK/kg live broiler) & 22.96 & 30.03 & 13.27 & 28.01 & 7.417 & 0.19 \\
\hline
\end{tabular}

SEM, standard error for difference between means; FCR, feed conversion ratio; TK, Bangladeshi currency (BD Taka).

Sale (BD Taka/kg live broiler) $=120.00=$ US $\$ 1.54$ dollar; $D_{1}=$ control diet (no multivitamin or acidifier); $D_{2}=D_{1}$ with $1 \mathrm{~mL}$ multivitamin/liter water; $D_{3}=D_{1}$ with $2 \mathrm{~mL}$ acidifier/liter water; $D_{4}=D_{1}$ with $1 \mathrm{~mL}$ multivitamin and $2 \mathrm{~mL}$ acidifier/liter water. 
Table 3. Effect of multivitamin or acidifier on lipid profiles of blood of broiler chickens at 35 days of age

\begin{tabular}{|c|c|c|c|c|c|c|}
\hline \multirow{2}{*}{ Lipid profile } & \multicolumn{4}{|c|}{$\operatorname{Diet}^{1)}(D)$} & \multirow{2}{*}{$\begin{array}{c}\text { SEM value } \\
\text { D }\end{array}$} & \multirow{2}{*}{$p$-value } \\
\hline & $\mathrm{D}_{1}$ & $\mathrm{D}_{2}$ & $D_{3}$ & $\mathrm{D}_{4}$ & & \\
\hline Total cholesterol (mg/dL) & 206.83 & 227.32 & 186.92 & 229.44 & 10.22 & 0.01 \\
\hline Triglyceride (mg/dL) & 204.53 & 231.17 & 205.76 & 208.64 & 3.15 & 0.01 \\
\hline $\mathrm{HDL}(\mathrm{mg} / \mathrm{dL})$ & 85.87 & 115.91 & 79.45 & 100.27 & 9.96 & 0.03 \\
\hline LDL (mg/dL) & 80.39 & 124.53 & 76.67 & 101.45 & 10.14 & 0.01 \\
\hline
\end{tabular}

SEM, standard error for difference between means; HDL, high density lipoprotein; LDL, low density lipoprotein.

${ }^{1)} \mathrm{D}_{1}=$ control diet (no multivitamin or acidifier); $\mathrm{D}_{2}=\mathrm{D}_{1}$ with $1 \mathrm{~mL}$ multivitamin/ liter water; $\mathrm{D}_{3}=\mathrm{D}_{1}$ with $2 \mathrm{~mL}$ acidifier/liter water; $\mathrm{D}_{4}=\mathrm{D}_{1}$ with $1 \mathrm{~mL}$ multivitamin and $2 \mathrm{~mL}$ acidifier/liter water.

Of the test diets, the highest live weight and the lowest FCR were observed in diet $\mathrm{D}_{4}$ followed by $\mathrm{D}_{2}$ and $\mathrm{D}_{3}$, respectively. Dietary group $\mathrm{D}_{2}$ had $0 \%$ mortality, and the mortality of $6.67 \%, 8.33 \%$, and $16.67 \%$ were observed in $\mathrm{D}_{1}, \mathrm{D}_{4}$, and $\mathrm{D}_{3}$, respectively. No differences were observed among the dietary groups in terms of feed intake, production cost and net profit ( $p>0.05$ ). However, evidently but not statistically, the highest net profit was observed in $\mathrm{D}_{2}$, followed by $\mathrm{D}_{4}, \mathrm{D}_{1}$, and $\mathrm{D}_{3}$, respectively.

Lipid profiles of blood of broiler chickens in different dietary groups: The dietary groups; $\mathrm{D}_{1}$ (control diet, no multivitamin or acidifier), $\mathrm{D}_{2}\left(\mathrm{D}_{1}\right.$ with supplementation of $1 \mathrm{~mL}$ multivitamin/ liter drinking water), $D_{3}\left(D_{1}\right.$ with supplementation of $1 \mathrm{~mL}$ acidifier/liter drinking water) and $\mathrm{D}_{4}\left(\mathrm{D}_{1}\right.$ with supplementation of $1 \mathrm{~mL}$ multivitamin and $2 \mathrm{~mL}$ acidifier/liter drinking water) were significantly different in respects of total cholesterol $(\mathrm{p}<0.01)$, HDL $(\mathrm{p}<0.05)$, and LDL $(\mathrm{p}<0.05)($ Table 3$)$. There was no significant difference between dietary groups for TG ( $p>0.05)$. Triglyceride tended to be increased in diet $\mathrm{D}_{2}$. The highest amount of total cholesterol was observed in diet $\mathrm{D}_{4}$ followed by $\mathrm{D}_{2}, \mathrm{D}_{1}$, and $\mathrm{D}_{3}$, respectively. However, the highest amount of HDL and LDL were observed in diet $\mathrm{D}_{2}$, followed by $\mathrm{D}_{4}, \mathrm{D}_{1}$, and $\mathrm{D}_{3}$, respectively. Therefore, $\mathrm{D}_{3}$ reduced lipid profiles in the blood of broiler chickens. In terms of lipid profiles content, $\mathrm{D}_{3}$ may be a suitable dietary group followed by $\mathrm{D}_{1}, \mathrm{D}_{4}$, and $\mathrm{D}_{2}$, respectively.

\section{Experiment 2}

Growth performance of broiler fed diet with or without Azolla or blending multivitamin and acidifier at 35 days of age: The dietary groups; $\mathrm{T}_{1}$ (control diet), $\mathrm{T}_{2}$ (5\% Azolla in the diet), $\mathrm{T}_{3}$
(7\% Azolla in the diet), and $\mathrm{T}_{4}$ ( $\mathrm{T}_{1}$ with supplementation of $1 \mathrm{~mL}$ multivitamin and $1 \mathrm{~mL}$ acidifier/liter water) were significantly different in terms of live weight $(\mathrm{p}<0.05)$, feed intake $(\mathrm{p}<0.001)$, FCR $(\mathrm{p}<0.01)$, mortality $(\mathrm{p}<0.01)$, production cost $(\mathrm{p}<0.05)$, and net profit $(\mathrm{p}<0.05)$ (Table 4). The highest live weight of broilers was observed in diet $\mathrm{T}_{4}$, followed by $\mathrm{T}_{1}, \mathrm{~T}_{3}$, and $\mathrm{T}_{2}$, respectively. However, the highest feed consumption of broilers was observed in diet $\mathrm{T}_{4}$, followed by $\mathrm{T}_{3}, \mathrm{~T}_{1}$, and $\mathrm{T}_{2}$, respectively. The highest FCR was recorded in $\mathrm{T}_{3}$, and the lowest in $\mathrm{T}_{2}$ and $\mathrm{T}_{1}$, and intermediate in diet $\mathrm{T}_{4}$. The highest mortality was obtained in diet $\mathrm{T}_{1}$, followed by $\mathrm{T}_{4}, \mathrm{~T}_{2}$, and $\mathrm{T}_{3}(0 \%$ mortality), respectively. The lowest production cost affected net profit, and obtained the highest net profit in $\mathrm{T}_{2}$ followed by $\mathrm{T}_{3}, \mathrm{~T}_{1}$, and $\mathrm{T}_{4}$, respectively. Therefore, considering FCR, mortality, production cost and net profit, $\mathrm{T}_{2}$ was the best performer among the dietary groups. The dietary group $\mathrm{T}_{3}$ may also be suitable for broiler production in terms of mortality, production cost and net profit.

Lipid profiles of blood of broiler chickens in different dietary groups: The amount of total cholesterol $(\mathrm{p}<0.05), \mathrm{TG}(\mathrm{p}<0.01)$, HDL $(p<0.05)$ were significantly different among the dietary groups; $\mathrm{T}_{1}$ (control diet), $\mathrm{T}_{2}$ (5\% Azolla in the diet), $\mathrm{T}_{3}(7 \%$ Azolla in the diet) and $\mathrm{T}_{4}\left(\mathrm{~T}_{1}\right.$ with supplementation of $1 \mathrm{~mL}$ multivitamin and $1 \mathrm{~mL}$ acidifier/liter water) (Table 5). Dietary groups did not affect LDL ( $p>0.05)$. However, LDL in the blood of broilers tended to decrease in case of $\mathrm{T}_{2}$ and $\mathrm{T}_{3}$ compared to $\mathrm{T}_{1}$ and $\mathrm{T}_{4}$. The increased amount of HDL was observed in $\mathrm{T}_{2}$ and $\mathrm{T}_{3}$ compared to $\mathrm{T}_{4}$ and $\mathrm{T}_{1}$. In addition, $\mathrm{T}_{2}$ showed the lowest amount of total cholesterol, TG and LDL followed by $\mathrm{T}_{3}, \mathrm{~T}_{1}$, and $\mathrm{T}_{4}$, respectively. Therefore, it appears that Azolla

Table 4. Effect of Azolla or combination of multivitamin and acidifier on growth performance of broiler chickens at 35 days of age

\begin{tabular}{|c|c|c|c|c|c|c|}
\hline \multirow{2}{*}{ Parameters } & \multicolumn{4}{|c|}{$\operatorname{Diet}(\mathrm{T})$} & \multirow{2}{*}{$\begin{array}{c}\text { SEM or } x^{2} \text { value } \\
T\end{array}$} & \multirow{2}{*}{$\mathrm{p}$-value } \\
\hline & $\mathrm{T}_{1}$ & $\mathrm{~T}_{2}$ & $\mathrm{~T}_{3}$ & $\mathrm{~T}_{4}$ & & \\
\hline Live weight (g/bird) & $1,440.05$ & $1,262.22$ & $1,358.33$ & $1,667.91$ & 91.688 & 0.01 \\
\hline Feed intake (g/bird) & $2,120.27$ & $1,846.59$ & $2,435.50$ & $2,700.79$ & 116.915 & $<0.01$ \\
\hline FCR (feed/live weight) & 1.48 & 1.47 & 1.79 & 1.62 & 0.058 & $<0.01$ \\
\hline Mortality (\%) & 15.74 & 3.70 & 0 & 11.47 & $x^{2}=28.749$ & $<0.01$ \\
\hline Production cost (TK/kg live broiler) & 93.09 & 90.16 & 91.41 & 110.64 & 5.451 & 0.02 \\
\hline Net profit (TK/kg live broiler) & 26.91 & 29.84 & 28.59 & 9.36 & 5.451 & 0.02 \\
\hline
\end{tabular}

SEM, standard error for difference between means; FCR, feed conversion ratio; TK, Bangladeshi currency (BD Taka).

Sale (BD Taka/kg live broiler) $=120.00=$ US\$ 1.54 dollar; $T_{1}=$ control diet (no Azolla or multivitamin and acidifier); $T_{2}=5 \%$ Azolla in the diet; $T_{3}=7 \%$ Azolla in the diet; $T_{4}=T_{1}$ with $1 \mathrm{~mL}$ multivitamin and $1 \mathrm{~mL}$ acidifier/liter water. 
Table 5. Effect of Azolla or combination of multivitamin and acidifier on lipid profiles of blood of broiler chickens at 35 days of age

\begin{tabular}{|c|c|c|c|c|c|c|}
\hline \multirow{2}{*}{ Lipid profile } & \multicolumn{4}{|c|}{$\operatorname{Diet}^{1)}(T)$} & \multirow{2}{*}{$\begin{array}{c}\text { SEM value } \\
\mathrm{T}\end{array}$} & \multirow{2}{*}{$p$-value } \\
\hline & $\mathrm{T}_{1}$ & $\mathrm{~T}_{2}$ & $\mathrm{~T}_{3}$ & $\mathrm{~T}_{4}$ & & \\
\hline Total cholesterol (mg/dL) & 223.10 & 210.12 & 218.50 & 237.48 & 7.466 & 0.04 \\
\hline Tri16glyceride (mg/dL) & 211.48 & 183.03 & 195.16 & 224.77 & 8.145 & $<0.01$ \\
\hline $\mathrm{HDL}(\mathrm{mg} / \mathrm{dL})$ & 80.05 & 109.84 & 103.89 & 95.62 & 7.962 & 0.03 \\
\hline LDL (mg/dL) & 133.83 & 78.73 & 91.71 & 102.13 & 30.03 & 0.36 \\
\hline
\end{tabular}

SEM, standard error for difference between means; HDL, high density lipoprotein; LDL, low density lipoprotein.

${ }^{1)} \mathrm{T}_{1}=$ control diet (no Azolla or multivitamin and acidifier); $\mathrm{T}_{2}=5 \%$ Azolla in the diet; $\mathrm{T}_{3}=7 \%$ Azolla in the diet; $\mathrm{T}_{4}=\mathrm{T}_{1}$ with $1 \mathrm{~mL}$ multivitamin and $1 \mathrm{~mL}$ acidifier/liter water.

has a remarkable impact on reducing lipid profiles of broiler chickens.

\section{DISCUSSION}

\section{Experiment 1}

Growth performance of broiler fed diet with or without multivitamin or acidifier at 35 days of age: Blending multivitamin and acidifier $\left(\mathrm{D}_{4}\right.$ : control diet with supplementation of $1 \mathrm{~mL}$ multivitamin and $2 \mathrm{~mL}$ acidifier/liter drinking water) affected live weight and FCR. This is why, improved live weight and FCR were observed on $\mathrm{D}_{4}$. In the current literature, no information has been found regarding the effect of blending multivitamin and acidifier on broiler chickens. A study reported the improvement of body weight of broiler chickens on a diet with multivitamin and enzyme mixture compared to the control or single supplementation of multivitamin or enzyme base diet [4]. Of the remaining diets, $\mathrm{D}_{2}$ (control diet with supplementation of $1 \mathrm{~mL}$ multivitamin/liter drinking water) was superior to $\mathrm{D}_{1}$ (control diet, no multivitamin or acidifier) or $\mathrm{D}_{3}$ (control diet with supplementation of $1 \mathrm{~mL}$ acidifier/liter drinking water) in terms of live weight, and FCR. It also reduced mortality because multivitamins provided essential vitamins and minerals required for recovering the deficit of essential nutrients in the diet of the birds, ultimately that affects production cost and net profit. The current findings corroborate the findings of Rahman et al [5]. Accordingly, $\mathrm{D}_{4}$ performed better than $\mathrm{D}_{1}$ and $\mathrm{D}_{3}$ in terms of mortality, production cost, and net profit. Ao et al [18] reported that acidification in the diet of broiler decrease feed intake and body weight gain, but acidification of diet with $\alpha$-galactosidase improve the nutrient retention and growth performance than using either $\alpha$-galactosidase or organic acid alone. In the current study, mixture of multivitamin and acidifier reduce mortality and production cost that affect to increase net profit evidently but not significantly. Therefore, diets $\mathrm{D}_{2}$ and $\mathrm{D}_{4}$ may be suitable for broiler production. However, $\mathrm{D}_{2}$ was more profitable than $\mathrm{D}_{4}$ for broiler production.

Lipid profiles of blood of broiler chickens in different dietary groups: Limited information regarding the effect of multivitamins and acidifiers or their combination on lipid profiles of broiler chickens can be found in the literature. The lowest amount of total cholesterol, $\mathrm{HDL}$, and LDL was observed in $\mathrm{D}_{3}$ of the diets.
There was no significance difference between diets with respect to $\mathrm{TG}(\mathrm{p}>0.05)$. However, $\mathrm{TG}$ was tended to increase in diet $\mathrm{D}_{2}$ supported by Brazoska et al [19]. They noted that there was no significant difference among diets (control, and control with $3,6,9 \mathrm{~g} / \mathrm{kg}$ of diet) in terms of LDL, TG, and total cholesterol. In the present study, $\mathrm{D}_{3}$ showed the lowest amount of cholesterol measured in the blood of broiler chickens $(p<0.01)$ which contradicted the findings of Dehghani-Tafti and Jahanian [20]. They found no effect of organic acids (citric and butyric acids) on serum HDL, LDL, and total cholesterol ( $p>0.05)$, except serum TG level which was affected by a low dietary CP level compared with a high dietary CP level. Jia et al [21] noted the decreasing amount of total cholesterol, and triglyceride in blood serum of broilers on diets containing lower levels of $\alpha$-lipoic acid (LA), and acetyl-L-carnitine (ALC), and an increased amount of nonesterified fatty acid, lipoprotein lipase, and lipase in blood serum when broilers were provided increasing levels of LA or ALC in the diet.

\section{Experiment 2}

Growth performance of broiler fed diet with or without Azolla or blending multivitamin and acidifier at 35 days of age: The highest live weight and feed intake was observed in $\mathrm{T}_{4}$ (control diet with supplementation of $1 \mathrm{~mL}$ multivitamin and $1 \mathrm{~mL}$ acidifier/liter water) among the diets because of the effect of multivitamin and acidifier. Multivitamin provides essential vitamin and minerals that affect improving body weight [4]. On the other hand, acidifier reduces the production of toxic components by bacteria and the colonization of pathogens on the intestinal wall resulting in an improvement of digestibility of protein, vitamin and minerals that leads to improved body weight gain and feed conversion efficiency $[6,7]$. This is why a mixture of multivitamin and acidifier improved growth and feed intake noted in the present study. However, diet $\mathrm{T}_{2}$ (5\% Azolla in the diet) showed the lowest FCR, production cost but the highest amount of net profit among the diets. Of the other three diets, $\mathrm{T}_{3}$ (7\% Azolla in the diet) was superior to $\mathrm{T}_{1}$ (control diet) or $\mathrm{T}_{4}$ in terms of production cost, net profit and mortality $(0 \%)$, supported by Basak et al [12]; Balaji et al [13]; Namra et al [11]; Balaji et al [22]; Sujatha et al [23]; Nagashi et al [14]. They reported improving body weight, FCR and profitability with the inclusion of $5 \%$ Azolla in the diet of broilers. The lowest net profit was 
observed in $\mathrm{T}_{4}$ because of increasing feed cost affected by increasing feed intake, FCR and mortality. Dhumal et al [24] also suggested the use Azolla up to 5\% level replacing soybean meal in broilers' diet without any adverse effect on growth and carcass quality which is parallel to the current study. Subudhi and Singh [16] suggested to use 20\% fresh Azolla replacing commercial feed in the diet of chickens. Therefore, 5\% Azolla may be used in diet for profitable broiler production. Use of 7\% Azolla may also be profitable for broiler production as supported by Prabina and Kumar [15]. They observed increasing body weight $(1.99 \mathrm{~kg}$ ) by $2.6 \%$, and immunity of broiler in diet with 7.5\% Azolla compared to the control diet (1.93 kg).

Lipid profiles of blood of broiler chickens in different dietary groups: Information in the literature regarding the effect of Azolla on lipid profiles of chicken is scarce. In the present study, the lowest amount of total cholesterol $(\mathrm{p}<0.05)$ and TG $(\mathrm{p}<0.01)$ were measured in diet $\mathrm{T}_{2},(5 \%$ Azolla in the diet) and also the lowest amount of LDL ( $p>0.05)$ was in $\mathrm{T}_{2}$ among the diets. Therefore, $\mathrm{T}_{2}$ was superior compared to the rest diets in terms of cholesterol, TG and LDL content. Accordingly $\mathrm{T}_{3}$ (7\% Azolla in the diet) also reduced total cholesterol, TG and LDL ( $p>0.05)$ and increased HDL $(p<0.05)$ in the blood of broiler chicken in comparison with $\mathrm{T}_{1}$ and $\mathrm{T}_{4}$ (control diet with supplementation of $1 \mathrm{~mL}$ multivitamin and $1 \mathrm{~mL}$ acidifier/liter water). Balaji et al [13] and Balaji et al [22] observed the lower amount of cholesterol in the blood of broiler chickens in diet with $4.5 \%$ Azolla supported the current findings. However, $\mathrm{T}_{1}$ (control) showed lower values of lipid profiles in the blood of broiler chickens compared to $\mathrm{T}_{4}$. Therefore, it has been found that $\mathrm{T}_{2}$ may be the suitable dietary group in respect to lipid profiles of broilers. Similarly $\mathrm{T}_{3}$ (7\% Azolla) may also be a suitable dietary group for broiler production in terms of lipid profiles content.

In conclusion, the present study reveals that diets containing multivitamin, blending $1 \mathrm{~mL}$ multivitamin and $2 \mathrm{~mL}$ acidifier, and $5 \%$ or $7 \%$ Azolla are suitable for producing safe and profitable broilers because of reduced FCR, mortality, production cost, and improving net profit. Azolla and acidifier reduced total cholesterol, LDL, TG, and increased HDL in the blood of broiler. Moreover, of the diets, $\mathrm{T}_{2}$ showed the highest net profit. Therefore, considering net profit and lipid profiles content of blood of broiler, 5\% Azolla may be the most suitable feed item for producing safe and profitable broiler. The 7\% Azolla may also be used in diet for producing safe and profitable broiler. However, more studies are needed to confirm the current findings prior to suggesting using Azolla in the poultry industry.

\section{CONFLICT OF INTEREST}

We certify that there is no conflict of interest with any financial organization regarding the material discussed in the manuscript.

\section{ACKNOWLEDGMENTS}

The authors are grateful to Research Management Committee (RMC), Bangabandhu Sheikh Mujibur Rahman Agricultural University (BSMRAU), Gazipur, Bangladesh for providing fund to carry out research in BSMRAU poultry farm. The authors are also grateful to Japan Society for the Promotion of Science (JSPS) for providing fellowship to do research, and prepare scientific article during stay in Japan.

\section{REFERENCES}

1. Ward, NE. Commercial vitamin supplementation for poultry. Poult Adv 1996;29:29-50.

2. Almeida AM de, Zuber U. The effect of Naked Neck genotype (Nana), feeding and outdoor rearing on growth and carcass characteristics of free range broilers in a hot climate. Trop Anim Health Prod 2010;42:99-107.

3. Garcia FQM, Murakami AE, Durate CR A, et al. Use of vitamin $\mathrm{D}_{3}$ and its metabolites in broiler chicken feed on performance, bone parameters and meat quality. Asian-Astralasian J Anim Sci 2013; 26:408-15.

4. Paul RC, Ahmad N, Moinuddin MA, Hasan N. Effects of administration of multivitamins and enzymes for broilers either single or in combination on body weight and haematobiochemical parameters. J Bangladesh Agric Univ 2010;8:39-44.

5. Rahman MA, Parvin MS, Sarker RR, Islam MT. Effects of growth promoter and multivitamin-mineral premix supplementation on body weight gain in broiler chickens. J Bangladesh Agric Univ 2012; 10:245-8.

6. Richards JD, Gong J, Delange CEM. The gastrointestinal microbial and its role in monogastric nutrition and health with an emphasis on pigs; current understanding possible modulations and New Technologies studies. Canadian J Anim Sci 2005;85:421-35.

7. Adil S, Banday T, Bhat GA, Mir MS, Rehman M. Effect of dietary supplementation of organic acids on performance, intestinal histomorphology and serum biochemistry of broiler chicken. Vet Med Int 2010;2010:Article ID 479485.

8. Ogunwole OA, Abu OA, Adepoju IA. Performance and carcass characteristics of broiler finishers fed acidifier based diets. Pakistan J Nutr 2011;10:631-6.

9. Lejeunea A, Cagauana A, Vanhove C. Azolla research and development recent trends and properties. Symbiosis 1999;27:333-51.

10. Alalade OA, Lyayi EA. Chemical composition and the feeding value of Azolla (Azolla pinnata) meal for egg type chickens. Int J Poult Sci 2006;5:137-41.

11. Namra MMM, Hataba NA, Wahed M. The productive performance of growing chicks fed restricted diets supplemented with free Azolla. Egyptian Poult Sci 2010;30:747-62.

12. Basak B, Pramanik MAH, Rahman MS, Tarafdar SU, Roy BCAzolla (Azolla pinnata) is a feed ingredient in broiler ration. Int J Poult Sci 2002;1:29-34 
13. Balaji K, Jalaludeen A, Richard CR, Peethambaran PA, Senthilkumar S. Effect of dietary inclusion of Azolla (Azolla pinnata) on production performance of broiler chicken. Indian J Poult Sci 2009;44:195-8.

14. Nagashi H, Khojasteh S, Jafari M. Investigation of the effect of different levels of Azolla (Azolla pinnata) on performance and carcass characteristics of Cobb broiler chicks. Int J Farming and Allied Sci 2014;3:45-9.

15. Prabina BJ, Kumar K. Dried Azolla as a nutritionally rich cost effective and immuno-modulatory feed supplement for broilers. Asian J Anim Sci 2010;5:20-2.

16. Subudhi BPR, Singh PK. Nutritive value of the water fern Azolla pinnata for chicks. Poult Sci 1978;57:378-80.

17. Freed R. Developed a computer statistical software package program MSTAT-C. Project Co-ordinator, Dept. of Crop and Soil Science, Michigan state University. East Lansing, MI: Michigan state University, 1994.

18. Ao T, Cantor AH, Pescatore AJ, et al. Effect of enzyme supplementation and acidification of diets on nutrient digestibility and growth performance of broiler chicks. Poult Sci 2009;88:111-7.
19. Brzoska F, Sliwinski B, Rutkowska OM. Effect of dietary acidifier on growth, mortality, post-slaughter parameters and meat composition of broiler chickens. Annals Anim Sci 2013;13:85-96.

20. Dehghani-Tafti N, Jahanian R. Effect of supplemental organic acids on performance, carcass characteristics, and serum biochemical metabolites in broilers fed diets containing different crude protein levels. Anim Feed Sci Technol 2016;211:109-16.

21. Jia R, Bao YH, Zhang Y, et al. Effects of dietary a-lipoic acid, acetylL-carnitine, and sex on antioxidative ability, energy, and lipid metabolism in broilers. Poult Sci 2014;93:2809-17.

22. Balaji K, Jalaludeen A, Kannan A. Effect of dietary Azolla on cholesterol content in broiler chicken. Indian Vet J 2010;87:478-80.

23. Sujatha T, Udhayakumar D, Kundu A, et al. Utilization of raw Azolla as a natural feed additive for sustainable production in Nicobari fowl. Anim Sci Rep 2013;7:146-52.

24. Dhumal MV, Siddiqui MF, Siddiqui MBA, Ayari PE. Performance of broilers fed on different levels of Azolla meal. Indian J Poult Sci 2009;44:65-8. 